\title{
Prohibitions in the Social and Legal Regulation: an International Aspect
}

\author{
Aleksandr V. Mal'ko and Veronika S. Khizhniak ${ }^{\mathrm{b} *}$ \\ a Saratov Branch of the Institute of State and Law of the RAS \\ 135 Tchernyshevskogo Str., Saratov, 410028, Russia \\ ${ }^{b}$ Saratov State Law Academy \\ 104 Tchernyshevskogo Str., Saratov, 410056, Russia
}

Received 31.10.2019, received in revised form 25.11.2019, accepted 02.12.2019

This work is focused on the problems arising in imposing prohibitions in international relations; the authors identify the main legal and social aspects hindering creation of effective mechanism for implementing prohibitions in international relations and enlist possible ways of eliminating the possible problems.

The analysis of the international legal norms of institutionalizing prohibitions and practices of their implementation revealed that an effective implementation of prohibitions is often associated with the need to amend national legislation, as well as with the presence of Russia's own legal norms that make it possible to apply the norms of international law in the state directly, or to apply them jointly with the norms of the national law.

The absence of a universal international instrument governing the responsibility of states for breaching legal prohibitions makes it difficult to implement these prohibitions and comply with them, although states may follow the rules of the "Draft Articles on Responsibility of States for Internationally Wrongful Acts" as a document stating moral (political) prescriptions.

The main problems cumbering the development of an effective mechanism for implementation of prohibitions are the following: the absence of agreed international and domestic legal mechanisms for implementation of prohibitions; the reluctance of states to bear responsibilities; the attempts to mitigate the prosecution of citizens, especially officials; and failures to take adequate legal measures for resolving the problem.

The authors necessitate adoption of documents that could regulate the issues of international legal responsibility, though in a unipolar world it is very problematic and can even aggravate the situation. The mechanism developed under such conditions can reflect the position of only one state and therefore can result in consolidating an undesirable hierarchy of states in international relations. An effective legal mechanism of responsibility for the violation of prohibitions in international relations can arise only in a multipolar world. It is also necessary to abide the basic principles of international law, to strengthen international cooperation and

(C) Siberian Federal University. All rights reserved

* Corresponding author E-mail address: i_gp@ssla.ru; k_kmp@ssla.ru ORCID: 0000-0003-3204-9696 (Mal'ko); 0000-0001-7261-515X (Khizhnyak)

This work is licensed under a Creative Commons Attribution-NonCommercial 4.0 International License (CC BY-NC 4.0). 
improve the mechanisms of international legal regulation. These efforts also call forth the establishment of a multipolar world.

Keywords: prohibitions, social regulation, international law, international relations.

Research area: economics.

Citation: Mal'ko, A.V., Khizhniak, V.S. (2019). Prohibitions in the social and legal regulation: an international aspect. J. Sib. Fed. Univ. Humanit. Soc. Sci., 12(12), 2230-2240. DOI: $10.17516 / 1997-1370-0532$.

\section{Introduction}

Prohibition is one of the oldest ways of regulating relations in societies. Nevertheless, prohibitions have not been thoroughly studied in the works pertaining either to branches of law, or to the general theory of law, though they are important components in the process of legal regulation. This fact makes their consideration particularly topical for the general theory of state and law. Legal prohibitions are inextricably linked with moral prohibitions, which contribute to more effective legal regulation (Mal'ko, 2018).

Prohibition is one of the most important means of emergence and evolution of civilization (Ponomarenkov, 2018); therefore, its role in the development of relations at the international level is difficult to overestimate. Unfortunately, the international legal aspect of this problem rarely becomes the object of legal research. At the same time, the problem of implementation and observance of norms and prohibitions especially in international relations is one of the most complicated ones; one can compare it with the problem of implementation of international sanctions. Both sanctions and prohibitions are aimed at a certain limitation of State sovereignty and at application of measures forcing the States to fulfill their responsibilities. In the international law there are prohibitions relating to the moral responsibilities of States, which are in fact their political responsibilities. The implementation of prohibitions is problematical owing to that it is not always possible to control their enforcement. Observance of moral (political) prohibitions or application of measures for their violation may be connected either with the prestige of the injured State or the State that is an offender in international relations, or with the specific features of their bilateral relations.

Problems related to prohibitions in social and legal regulation were examined within the philosophy of law by V.S. Nersesiants (2005), within the theory of state and law by S.S. Alekseev (1973), A.V. Mal'ko (2011; 2018), N.I. Matuzov (2004), M.M. Sultygov (1996) and others. Scholars engaged in the international law theory researches usually consider the problem of sanctions in the context of implementation 
of provisions taking into account the responsibility of international law subjects. These aspects were studied by Yu.N. Zhdanov (1999), E.A. Proshina (2006), G.N. Tunkin (1983), S.V. Chernichenko (1999) and others. In the foreign theory of international law this question was investigated by S. Chinkin (2001), M.P. Doxey (1987) and others.

At the same time, there have been no studies in the philosophy of law and in the theory of state and law which would have addressed the problem of compliance with prohibitions in international law. In the Russian theory of international law, this problem is usually reduced to responsibility issues, while it is much broader and affects such aspects as limitation of State sovereignty, protection of human rights and the environment, maintenance of peace and security in international relations. In the foreign theory of international law these aspects of the problem were covered by J. Shi (2018), M.G. Kearney (2007).

\section{Theoretical framework}

The research is based on the concept developed by H. Kelsen, according to whom the imperfection of international law is explained by the fact that its subjects establish their rules by themselves, and their centralized enforcement is not carried out by any special legislative, administrative, or judicial body (Kelsen, 1949). We also take into consideration G. Ellinek's theory of self-restriction, which the States may comply with. According to this theory, a sovereign State does not obey any supreme will, but can voluntarily restrict its sovereignty in favour of other States (Ellinek, 1908). The theory of the General will of $\mathrm{H}$. Trippel, who considered international law to be the result of the unification of the will of several States, also forms one of the conceptual basic components of the present research.

The theories mentioned above emphasize the facts that States establish prohibitions in international law voluntarily and that it is difficult to enforce them, since the very application of responsibility measures in international relations is challenging (Trippel, 1899). At the same time, according to the theory of the basic rule developed by $\mathrm{D}$. Anzilotti, the legal force of international law bases on a rule that is not to be argued - this is the principle of pacta sunt servanda (treaties must be observed), since the absence of such a rule turns international law into a set of purely moral obligations (Anzilotti, 1955).

Thus, prohibitions in international law are established by the will of its subjects, but they must be implemented by virtue of the basic principle of international law prescribing strict compliance with the obligations assumed. 


\section{Statement of the problem}

Prohibitions are as necessary in international law as sanctions. They are the responses to those acts that are unlawful and the commission of which may entail sanctions (the application of responsibility measures). Hence, both sanctions and prohibitions are interrelated and limit the sovereignty of States. The process of implementing the norms represented by prohibitions in international law is burdened with the absence of an effective mechanism for the application of liability measures to entities that do not comply with the prohibitory norms.

\section{Methods}

The methodological basis of the research is a dialectical approach to the subject of the study. It requires consideration of the problem in its interrelations and interdependencies, stemming from the characteristic features of international law as an independent legal system and the specifics of the composition of entities involved into international legal relations prescribed by international law. The formal legal method was used for analyzing the norms of law, legal practice, and identifying trends in the institutionalization and enforcement of prohibitions in international law. Sociological method allowed the authors to take into account a set of social factors that lie outside the legal sphere and are attributed to the problem of compliance with prohibitions in international law.

\section{Discussion}

The implementation of prohibitions is expressed in abstention from any actions that violate them, that is, in their observance. One of the features of prohibitions' implementation established by international law is that in some cases implementation is subject to the adoption of norms by the domestic law. For example, treaties establishing the corpus delicti stipulate that States, which are their parties, shall establish responsibilities in their criminal legislation for the commission of the relevant internationally wrongful acts, e.g., for genocide, ecocide, terrorism, slave trade, counterfeiting, illegal drug traffic, and etc.

Article 2 Paragraph 1 of the United Nations Convention against Illicit Traffic in Narcotic Drugs and Psychotropic Substances of 1988, states: "In carrying out their obligations under the Convention, the Parties shall take necessary measures, including legislative and administrative measures, in conformity with the fundamental provisions of their respective domestic legislative systems". Paragraph 1 of Article 3 in this document 
states that "each Party shall adopt such measures as may be necessary to establish as criminal offences under its domestic law, when committed intentionally" (United Nations Convention against Illicit Traffic...). Article 5 of the UN Convention against Transnational Organized Crime reads: "Each State Party shall adopt legislative and other measures as may be necessary to establish as criminal offences, when committed intentionally" (United Nations Convention against Transnational Organized Crime...). A similar provision is represented in Paragraph 1 of Article 9 of the Council of Europe Convention on Laundering, Search, Seizure and Confiscation of the Proceeds from Crime and on the Financing of Terrorism (2005) and in other international documents regulating cooperation of States in the sphere of combating crime.

Thus, norms of international law often demand introduction of changes into the criminal legislation of a State. However, this is not the only way that States use to implement international prohibitory norms. It is also possible to apply such norms of international law directly. In the Russian Federation, this is possible for ratified international treaties in Part 4 of Article 15 of the Constitution of the Russian Federation (Konstitutsiia Rossiiskoi Federatsii...). In this case, the treaty enters the legal system and does not require the publication of any regulatory acts for its implementation on the territory of Russia. One more way is the joint application of international and domestic law, which also simplifies the procedure of applying the rules of international law.

Officials of States are responsible for violating the prohibitory norms of international law in accordance with the procedure provided for by domestic law. In some cases, the officials may be held liable by international bodies, e.g., based on the provisions of the Rome Statute of the International Criminal Court (1998).

States bear material or political (moral) responsibility for violating the prohibitory norms of international law. In fact, they are responsible for the unlawful actions of their officials. Similarly, they may be held liable for wrongful acts of their citizens who infringe international law. This situation can take place in two cases:

1. If a State has not fulfilled its obligations to bring its legislation in accordance with the norms of international law (that is, it has not institutionalized the criminal liability of individuals who violate the norms of international law).

2. If a State has brought its legislation in accordance with the norms of international law, but has not applied these norms, even if it was obviously necessary (that is, it has not carried out criminal prosecution, having lawful reasons for that).

A State itself can be held responsible for the breach of a prohibition only by the decision of an international body that has the authority to resolve such questions. These 
bodies are the Security Council and the International Court of Justice. As a result, the Security Council can take enforcement measures against States that with their internationally wrongful acts pose a threat to peace and security (Articles 39-42, 50 of the UN Charter) (UN Charter...). The International Court of Justice resolves interstate disputes and issues binding decisions for the parties in the dispute. Sometimes disputes concern violation of the prohibitory norms of international law. For instance, the wellknown case of Nicaragua against the United States, examined by the International Court of Justice in 1986, concerned the violation by the United States of the prohibition on the use of force existing in international law based on one of its fundamental principles. The court decided the case in favour of Nicaragua (Nicaragua $v$. the United States..., 1986).

It should be noted that in case any party "fails to perform the obligations incumbent upon it under a judgment rendered by the Court, the other party may have recourse to the Security Council, which may, if it deems necessary, make recommendations or decide upon measures to be taken to give effect to the judgment" (Part 2, Article 94, Charter of the United Nations) (UN Charter..., 1945). As a consequence, the binding nature of the decision is reinforced by the authority of the Security Council to take measures necessary to enforce it.

Practical realization of responsibility for violation of prohibitory norms in international law faces some problems described below.

1. A State can shield its citizens from the application to them of international legal responsibility measures, or impose too mild punishments for violation of the norms of international law in courts.

2. A State itself can evade from responsibility at the international level starting endless disputes with its counterparts or the injured States.

International organizations can also be accountable in international law, but there are also problems. Sometimes it is difficult to decide who really violated the rule of international law, an international organization or a Member-State. There is also the question: "Should States be responsible for the internationally wrongful acts of an international organization, if they were in fact caused by the actions of their officials?" Likewise, the issue of the obligations of an international organization to its members and non-participating States remains open.

The solution of questions of responsibility of the subjects of international law is intricate due to the fact that neither the Draft Articles on the Responsibility of States for Internationally Wrongful Acts (2001), nor the Draft Articles on the Responsibility 
of International Organizations (2011) have been adopted so far. Consequently, the prohibitions stated in these documents can only be of a moral and political nature for States, but not of a legal one. That is, they may be only a kind of social regulator.

In the field of establishing and implementing (enforcing) prohibitions in international law, there are a number of trends. Firstly, the tendency of a gradual increase in the number of prohibitions, which is connected with the spread over the last hundred years of norms of international law containing sanctions. At the same time, in international law, the increase in the number of prohibitions is not comparable to their number in the domestic law. Secondly, the establishment of prohibitions in international law affects their institutionalization in the domestic law through the duty of States to fulfill their obligations under international law and bring their legislation in accordance with it.

One can specify a number of features of implementation (observance) of prohibitions in international law.

1. The majority of prohibitions are established by mutual agreement of the States. The exception concerns only the basic principles of international law.

2. Prohibitions apply only to those States that are parties to international treaties with rare exceptions.

3. Prohibitions may be addressed to both individuals and legal entities, although they are not subjects of international law.

4. In modern international law, there is a tendency to increase the number of prohibitions.

5. Both international and domestic bodies participate in the process of implementing prohibitions.

6. Both international and domestic authorities can apply measures of responsibility for violations of prohibitions.

7. The main problem with the establishment of prohibitions in international law is that they restrict state sovereignty, which is not always acceptable to States, and therefore, they may refuse to recognize the legal force of the treaty in relation to themselves.

8. The main problem related to the observance and implementation of prohibitory norms of international law is that it claims both international and domestic legal mechanisms. The latter depend only on the will of the State concerned. That is why they are often quite effective at the national level. The establishment of international legal mechanisms depends on coherence between States as the main subjects of 
international law. Therefore, the development and implementation of such mechanisms is significantly complicated.

9. Application of the norms of responsibility for violation of prohibitions in international law is also impeded by the unwillingness of the States to bear a responsibility, by attempts to refrain from prosecution of their citizens, especially officials, and by failure to regulate this problem adequately.

\section{Conclusion}

Thus, the implementation of any prohibitions (moral, political, and legal) in modern international relations is laborious due to a variety of factors. It is possible to change the current situation by adopting documents regulating international legal responsibility. However, in a unipolar world this is very problematic and can only exacerbate the problem. The mechanism developed in such conditions will reflect the position of only one State and consolidate the undesirable hierarchy of States in international relations. An effective legal mechanism of responsibility for violation of prohibitions in international relations can arise only in a multipolar world.

In addition, the stabilization of international relations in the context of the processes of globalization and regionalization can be achieved through strict observance of the basic principles of international law, strengthening of international cooperation and the improvement of the mechanisms of international legal regulation. This requires strengthening the positions of the United Nations in international relations and building a multipolar world.

\section{References}

Alekseev, S.S. (1973). Pravovye zaprety v strukture sovetskogo prava [Legal prohibitions in the structure of the Soviet law]. In Pravovedenie [Jurisprudence], 5, 43-51.

Anzilotti, D. (1955). A course of international law. Vol. 1. Introduction - General theory. IV edition with addition of unpublished notes of the author and the Chapter on Lateranian agreements [Corso di diritto internazionale. Vol. 1 Introduzione - Teorie generali. IV edizione con l'aggiunta li note inedite dell'autore e di un capitolo sugli accordi lateranensi]. Padova, Cedam, 447 p.

Chernichenko, S.V. (1999). Teoriia mezhdunarodnogo prava [Theory of international law]. Moscow, NIMP, 336 p.

Chinkin, C. (2001). Alternatives to economic sanctions. In UN Sanctions in international law. The Hague, London, Boston, Kluwer law international, 381-391. 
Council of Europe Convention on Laundering, Search, Seizure and Confiscation of the Proceeds from Crime and on the Financing of Terrorism (2005). Available at: https://rm.coe.int/168008371f (accessed 5 September 2018).

Doxey, M.P. (1987). International sanctions in contemporary perspective. London, The Macmillan Press LTD, 151 p.

Draft Articles on the Responsibility of International Organizations (2011). Available at: http://legal.un.org/ilc/texts/instruments/english/draft_articles/9_11_2011. pdf (accessed 6 September 2018).

Draft Articles on the Responsibility of States for Internationally Wrongful Acts (2001). Available at: http://legal.un.org/ilc/texts/instruments/english/commentaries/9_6_2001.pdf

Ellinek, G. (1908). Obshchee uchenie o gosudarstve. Izdanie 2 [General teaching on State. $2^{\text {nd }}$ ed.]. Saint-Petersburg, "Izdanie Iuridicheskogo Knizhnogo Magazina N.K. Martynova", 560 p.

Kearney, M.G. (2007). The Prohibition of Propaganda for War in International Law. Oxford; New York, Oxford University Press, 274 p.

Kelsen, H. (1949). General Theory of Law and State. Cambridge, Harvard University Press, 516 p.

Konstitutsiia Rossiiskoi Federatsii: priniata na vsenarodnom golosovanii 12 dekabria 1993 (s popravkami ot 30 dekabria 2008; 5 fevralia, 21 iiulia 2014) [Constitution of the Russian Federation: Adopted by the Popular Vote on December 12, 1993 (as amended on December 30, 2008, February 5, July 21, 2014)]. In Sistema konsul'tant plus [Consultant Plus System]. Available at: http://www.consultant.ru/ document/cons_doc_LAW_28399/(accessed 5 September 2018).

Mal'ko, A.V. (2011). Stimuly i ogranicheniia v prave: teoretiko-informatsionnyi aspekt. 3-e izd. [Stimuli and restrictions in law: theoretical and informational aspect. $3^{\text {rd }}$ ed.]. Saarbrucken, LAPLAMBERT Academic Publishing, 360 p.

Mal'ko, A.V.(2018). O neobkhodimosti teorii zapretov v prave [On the necessity of the prohibition theory in law]. In Zaprety v prave i pravovoi politike: obshcheteoreticheskii $i$ otraslevoi aspekty [Prohibitions in law and legal policy: general theoretical and branch aspects]. Moscow, "INFRA-M", 5-20.

Matuzov, N.I. (2004). O printsipe "ne zapreshchennoe zakonom dozvoleno" [On the principle "what is not prohibited by law is allowed"]. In Teoriia gosudarstva i prava [Theory of state and law]. Moscow, "Iurist", 61-64.

Nersesiants, V.S. (2005). Filosofiia prava [Philosophy of law]. Moscow, "Norma", $644 \mathrm{p}$. 
Nicaragua v. the United States. Decision of the International Court of Justice of (1986). Available at: https://www.icj-cij.org/files/case-related/70/070-19860627JUD-01-00-EN.pdf/ (accessed 6 September 2018).

Ponomarenkov, V.A. (2018). Sotsial'no-faktornaia priroda zapreta v pravovoi politike i pravovoi zhizni obshchestva [Social and factor nature of a prohibition in the legal policy and legal life of the society]. In Zaprety $v$ prave i pravovoi politike: obshcheteoreticheskii $i$ otraslevoi aspekty [Prohibitions in law and legal policy: general theoretical and branch aspects]. Moscow, "INFRA-M", 364-373.

Proshina, E.A. (2006). Mezhdunarodno-pravovaia otvetstvennost' gosudarstv [International legal responsibility of states]. Moscow, Moscow University of the RF Ministry of Internal Affairs, $24 \mathrm{p}$.

Rome Statute of the International Criminal Court (1998). Available at: http://legal. un.org/ola (accessed 6 September 2018).

Shi, J. (2018). Prohibition of Use of Force in International Law. In Chinese Journal of International Law, 17, 1-14.

Sultygov, M.M. (1996). Zapret kak metod pravovogo regulirovaniia [Prohibition as a method of legal regulation]. Saint-Petersburg, St. Peterburg Institute of Law, 19 p.

Trippel, H. (1899). National law and the law of the country [Volkerrecht und Landesrecht]. Leipzig, Hirshfeld, 452 p.

Tunkin, G.N. (1983). Pravo i sila v mezhdunarodnoi sisteme [Law and force in the international system]. Moscow, "Mezhdunarodnye otnosheniia", 200 p.

UN Charter (1945). Available at: http://www.un.org/en/sections/un-charter/uncharter-full-text (accessed 6 September 2018).

UN Convention against Transnational Organized Crime and the Protocols thereto (2000). Available at: http://www.unodc.org (accessed 5 September 2018).

United Nations Convention against Illicit Traffic in Narcotic Drugs and Psychotropic Substances (1988). Available at: http://www.unodc.org (accessed 5 September 2018).

Zhdanov, Iu.N. (1999). Prinuditel'nye mery v mezhdunarodnom prave [Compulsory norms in international law]. Moscow, MGIMO-University of Ministry of International Affairs in RF. 28 p. 


\title{
Запреты в социально-правовом регулировании: международный аспект
}

\author{
А.В. Малько \\ ${ }^{a}$ Саратовский филиал Института государства и права РАН \\ Россия, 410028, Саратов, ул. Чернышевского, 135 \\ ${ }^{6}$ Саратовская государственная юридическая академия \\ Россия, 410056, Саратов, ул. Чернышевского, 104
}

В данной работе рассмотрены проблемы, возникающие при реализации запретов в международных отношениях, а также определены основные аспекты правового и сочиального характера, препятствуюшие выработке эффективного механизма реализачии запретов в международных отномениях, и сформированы возможные пути их устранения.

Анализ международно-правовых норм институционализащии запретов и практики их использования показал, что эффективное применение запретов часто связано с необходимостью внесения поправок в национальное законодательство, а также с наличием внутригосударственных правовых норм, позволяющих непосредственно применять нормы международного права на территории государства или использовать их совместно с нормами национального права.

Отсутствие универсального международного документа, регулирующего ответственность государств за нарушение правовых запретов, затрудняет применение этих запретов и их соблюдение, хотя государства могут следовать правилам «Проекта статей об ответственности государств за международно-противоправнье деяния» как документа с указанием моральных (политических) норм.

Основные проблемы, препятствующие разработке эффективного механизма реализации запретов, были определены следующим образом: отсутствие согласованных международных и внутренних правовых механизмов для реализации запретов; нежелание государств нести ответственность; попьтки смягчить преследование граждан, особенно должностных лии; неспособность принять адекватные правовые меры для решения проблемы. Авторы заявляют о необходимости принятия документов, которые могли бы регулировать вопросы международно-правовой ответственности, хотя в однополярном мире это очень проблематично и может даже усугубить ситуацию. Механизм, разработанный в таких условиях, может отражать позицию только одного государства и, следовательно, способен привести к консолидации нежелательной иерархии государств в международных отношениях. Эффективный правовой механизм ответственности за нарушение запретов в международных отношениях может возникнуть только в многополярном мире. В свою очередь, необходимо строго соблюдать основные принципы международного права, укреплять международное сотрудничество и совершенствовать механизмы международно-правового регулирования. Эти усилия также требуют создания многополярного мира.

Ключевые слова: запреть, сочиальное регулирование, международное право, международнье отношения.

Научная специальность: 08.00.00 - экономические науки. 